\title{
ASSESSMENT OF CONTENT OF FAT AND TOCOPHEROLS IN SEEDS OF AMARANTHUS IN RELATION TO DIVERSIFIED FERTILIZATION WITH MACROELEMENTS
}

\author{
OCENA ZAWARTOŚCI TŁUSZCZU I TOKOFEROLI \\ W NASIONACH SZARŁATU W ZALEŻNOŚCI \\ OD ZRÓŻNICOWANEGO NAWOŻENIA MAKROELEMENTAMI
}

\begin{abstract}
This study is based on the field experiment carried out in the years 2007-2008, on an individual farmer's field in Bodaczow, near Zamosc. The aim of the experiment was to determine the influence of different dosages of NPK on the content of fat and homologous tocopherols in the seeds of two varieties of amaranth: Rawa and Aztek. The experiment was started on brown soil made from loess, with high content of $\mathrm{P}, \mathrm{K}$ and $\mathrm{Mg}$, and slightly acidic reaction ( $\mathrm{pH}$ in $\left.1 \mathrm{~mol} \mathrm{KCl} \cdot \mathrm{dm}^{-3}-5.8\right)$. The experiment was started with split-plot method in three repetitions, and involved: two varieties of amaranthus (Rawa and Aztek), and 4 variants of fertilization with macroelements NPK $\left(\mathrm{kg} \cdot \mathrm{ha}^{-1}\right)\left(\mathbf{1}\right.$ - object without any fertilization, 2 - $70 \mathrm{~N}, 50 \mathrm{P}_{2} \mathrm{O}_{5}, 50 \mathrm{~K}_{2} \mathrm{O} ; 3$ - $90 \mathrm{~N}, 60 \mathrm{P}_{2} \mathrm{O}_{5}$, $60 \mathrm{~K}_{2} \mathrm{O} ; 4-130 \mathrm{~N}, 70 \mathrm{P}_{2} \mathrm{O}_{5}, 70 \mathrm{~K}_{2} \mathrm{O}$ ). The content of fat was marked in the seed with Soxhlet's method, and $\alpha-, \beta-, \gamma$ - and $\delta$-tocopherol with high performance liquid chromatography (HPLC). The study reveals that the amount of accumulated fat in the seeds of amaranthus largely depended on the variety of the plant and variant of fertilization with macroelements. Significantly high content of fat in the seeds was found at the fourth (the highest) level of fertilization with NPK. Higher content of fat in the seeds was determined in Aztec variety than Rawa. The varieties of amaranthus varied considerably in the content of: $\alpha-, \beta$-tocopherol and their total amount. Higher content of $\alpha$-tocopherol and its higher total amount was found in the seeds of Aztek variety, rather than Rawa. The seeds of Rawa variety had significantly more $\beta$-tocopherol than Aztek variety. Fertilization with growing dosages of NPK had a significant, positive influence only on the amount of $\alpha$-tocopherol and its total amount.
\end{abstract}

Keywords: amaranthus, content of fat, tocopherols

Amaranthus is a crop (pseudo-crop). It is also one of the oldest plants cultivated in the world [1]. Its extraordinary nutritive aspects were valued by the Aztecs and the Incas [2-4]. The prospects of reintroduction of this plant for widespread cultivation appeared in the $70 \mathrm{~s}$ of the $20^{\text {th }}$ century, because new highly nutritive plants were in demand. Various studies confirmed that amaranthus has a very favorable chemical composition of seed, which differentiates it from other crops [5-10]. Another advantage of amaranthus is high productivity.

\footnotetext{
${ }^{1}$ The Faculty of Agricultural Sciences in Zamosc, The University of Life Sciences in Lublin, ul. Szczebrzeska 102, 22-400 Zamość, Poland, phone: +48 8467727 56, email: barbara.skwarylo@up.lublin.pl
} 
Among crops, amaranthus stands out as a plant with the highest content of fat (5 to 9\% in dry seed mass) [11]. Oil obtained from amaranthus seeds has high content of unsaturated fatty acids (oleic acid, linoleic acid, linolenic acid) [12, 13]. Some of them, eg linoleic acid, linolenic acid belong to exogenous acids that are crucial for human body [8, 14]. They play an important role in hormone synthesis, build of cell membranes and regulation of their permeability $[14,15]$. Many valuable components are dissolved in the oil obtained from amaranthus seeds [8], such as squalene, tocopherols, and tocotrienols [7, 8, 14]. Squalene is used in production medicines that counteract body ageing processes. Antioxidant properties of squalene are investigated by many scientists. The studies conducted on animals revealed that squalene is a protective factor against cardiac infarction which is caused by isoproteronol [15]. It is most probable that it is owing to squalene that the mechanism of blocking of induction of lipid peroxidation is triggered $[15,16]$. Squalene also decreases the amount of cholesterol in blood [17-19]. Tocopherols and tocotrienols are natural antioxidants [20] which support human body immune system and protect vitamin $\mathrm{A}$ and unsaturated fatty acids, membrane lipids and reserve lipids [21]. Tocopherols probably restrict lipid peroxidation [22]. The studies confirm that $\alpha$-tocopherol is the strongest antioxidant [23, 24]. It should be noted, that higher plants are the main source of tocopherols [24], however, the amount of tocopherols in a plant depends on the stage of development of the plant. An increased amount of tocopherols, especially $\alpha$-, $\beta$-tocopherols, was observed in the period of fruit ripening [21].

The aim of this study was to estimate the content of fat and tocopherols in the seeds of Polish varieties of amaranthus - Rawa and Aztek, in conditions of diversified fertilization with macroelements.

\section{Material and methods}

The field experiment was carried out in the years 2007-2008 on an individual farmer's field in Bodaczow, near Zamosc, using two varieties of amaranthus for seeds (Amaranthus cruentus L.): Rawa and Aztek. The experiment was started on brown soil made from loess, with high content of $\mathrm{P}, \mathrm{K}$ and $\mathrm{Mg}$, and slightly acidic reaction $\left(\mathrm{pH}\right.$ in $\left.1 \mathrm{~mol} \mathrm{KCl} \cdot \mathrm{dm}^{-3}-5.8\right)$. The experiment was started with split-plot method in three repetitions. The area of a microplot for sewing was $1 \mathrm{~m}^{2}$.

The experiment involved: two varieties of amaranthus (Rawa and Aztek) and 4 variants of fertilization with macroelements NPK $\left[\mathrm{kg} \cdot \mathrm{ha}^{-1}\right](\mathbf{1}$ - object without any fertilization, 2 - $70 \mathrm{~N}$, $50 \mathrm{P}_{2} \mathrm{O}_{5}, 50 \mathrm{~K}_{2} \mathrm{O} ; 3$ - $90 \mathrm{~N}, 60 \mathrm{P}_{2} \mathrm{O}_{5}, 60 \mathrm{~K}_{2} \mathrm{O} ; 4$ - $130 \mathrm{~N}, 70 \mathrm{P}_{2} \mathrm{O}_{5}, 70 \mathrm{~K}_{2} \mathrm{O}$ ). Fertilization with $\mathrm{P}$ (polifoska) and $\mathrm{K}$ (potassium salt) was used in autumn. $\mathrm{N}$ (ammonium salt) was sown in spring in two separate dosages (one was used before sowing, and the other on month after the plants started growing).

The seeds of the two varieties of amaranthus were sown in the third decade of May, and the distance between the rows was $48 \mathrm{~cm}$. Cultivation and plant care procedures were in accordance with commonly used rules of agritechnique. The seeds were harvested in the second half of October.

The content of fat in the seeds was marked with Soxhlet's method in Central Analytic Laboratory in the University of Life Sciences in Lublin. Moreover, the following were determined: $\alpha-, \beta-, \gamma$ - and $\delta$-tocopherol with high performance liquid chromatography (HPLC) - Laboratory of the Institute of Food Analysis, Department of Biochemistry and 
Food Analysis, Faculty of Food and Nutrition Sciences, University of Life Sciences in Poznan.

The results obtained in this paper were statistically elaborated and the smallest significant discrepancies were calculated by means of Tukey's test with $5 \%$ error risk. The results presented in this paper are mean values from two years.

\section{Results and discussion}

The study that was carried out reveals, that the content of fat in amaranthus seeds depends greatly on the variety of the plant and the dosage of fertilization with macroelements (Table 1)). The mean amount of fat in the seeds of Aztek variety was about $7.70 \%$ higher than observed for Rawa variety (Table 1).

Content of fat in seeds [\%]

Table 1

\begin{tabular}{|c|c|c|c|}
\hline Fertilization & Rawa variety & Aztec variety & Mean \\
\hline 1 & 5.75 & 6.60 & 6.18 \\
\hline 2 & 6.35 & 6.70 & 6.53 \\
\hline 3 & 6.40 & 6.75 & 6.56 \\
\hline 4 & 6.42 & 6.80 & 6.61 \\
\hline Mean & 6.23 & 6.71 & - \\
\hline
\end{tabular}

$\operatorname{LSD}_{0.05}$ fertilization 0.34 ; variety 0.23 .

Many studies show that different varieties of amaranthus vary in chemical composition of seeds, also in content of fat $[25,26]$. The content of fat obtained in this experiment in the seeds of Polish varieties of amaranthus are coherent with the results obtained earlier [27].

The highest content of fat in the seeds of amaranthus was found after the fourth (the highest) dosage of macroelements had been used (6.23\% for Rawa variety and $6.80 \%$ for Aztek variety (Table 1). The mean content of fat in amaranthus seeds that was obtained in the experiment (Rawa variety $-6.23 \%$, Aztek variety $-6.71 \%$ ) is higher than this obtained by Tomoskozia et al [25] $-5.95 \%$. A higher content of fat in amaranthus seeds was obtained by other authors - Dodok et al [12] - 7.32\%, Ratusz and Wirkowska [28] - 7.10\%. Gajewska et al [29] obtained a higher mean content of fat in seeds $-7.1 \%$ in their studies, at the noted range of fat $5.9 \div 9.3 \%$.

The amount of accumulated fat in seeds depends on the variety of amaranthus and dosages of fertilization with macroelements that is used [30]. The studies of Bressani et al [30] reveal that fertilization of Amaranthus caudatus species with increasing dosages of macroelements favored accumulation of fat, whereas fertilization of Amaranthus cruentus species resulted in a decreased amount of fat [30]. The investigation carried out in this paper show favorable effects of fertilization with increasing dosages of macroelements on accumulation of fat in the seeds of Polish varieties of Amaranthus cruentus.

The occurrence of four homologs of tocopherol: $(\alpha-, \beta-, \gamma-$, and $\delta$-tocopherol) was observed in the seeds of Aztek variety of amaranthus, and two: $\alpha$ - and $\beta$-tocopherol in the seeds of Rawa variety. $\beta$-tocopherol was the dominant form in the seeds of both varieties of amaranthus (Table 2).

This study reveals that increasing dosages of fertilizers significantly influenced the total content of tocopherol and especially of $\alpha$-tocopherol (Table 2). 
Content of tocopherols in seeds of amaranthus $\left[\mathrm{mg} \cdot \mathrm{kg}^{-1} \mathrm{~d} . \mathrm{m}.\right]$

\begin{tabular}{|c|c|c|c|c|c|}
\hline \multirow[b]{2}{*}{ Fertilization } & \multicolumn{5}{|c|}{ Tocopherols } \\
\hline & $\alpha$ & $\boldsymbol{\beta}$ & $\gamma$ & $\delta$ & $\begin{array}{l}\text { Total content } \\
\text { of tocopherols }\end{array}$ \\
\hline \multicolumn{6}{|c|}{ Rawa variety } \\
\hline 1 & 10.2 & 38.4 & - & - & 48.6 \\
\hline 2 & 11.2 & 40.9 & - & - & 52.1 \\
\hline 3 & 14.0 & 40.2 & - & - & 54.2 \\
\hline 4 & 17.4 & 48.5 & - & - & 65.9 \\
\hline Mean & 13.2 & 42.0 & - & - & 55.2 \\
\hline \multicolumn{6}{|c|}{ Aztec variety } \\
\hline 1 & 14.8 & 35.4 & 3.9 & 15.7 & 69.8 \\
\hline 2 & 18.6 & 38.8 & 2.0 & 18.4 & 77.8 \\
\hline 3 & 19.4 & 39.8 & 4.0 & 15.5 & 78.7 \\
\hline 4 & 20.6 & 39.3 & 2.1 & 17.9 & 79.9 \\
\hline Mean & 18.4 & 38.3 & 3.0 & 16.9 & 76.6 \\
\hline $\begin{array}{c}\mathrm{LSD}_{0.05} \\
\text { fertilization }\end{array}$ & 3.4 & ns & ns & ns & 13.1 \\
\hline $\begin{array}{l}\mathrm{LSD}_{0.05} \\
\text { variety }\end{array}$ & 2.9 & 3.5 & ns & ns & 6.2 \\
\hline
\end{tabular}

Considerable differences in content of $\alpha$-, $\beta$-tocopherol and their total content in seeds were observed between the varieties of amaranthus. The mean amount of $\alpha$-tocopherol and its total amount in the seeds of Aztek variety were higher than in the seeds of Rawa variety by 39.4 and $38.8 \%$, respectively (Table 2). The seeds of Aztek variety contained less $\beta$-tocopherol (by about 9.7\%), as compared with Rawa variety. Generally speaking, the amount of $\beta$-tocopherol that was obtained in the seeds of amaranthus closely corresponded with the amount obtained by Gustone et al [31], and higher than that obtained by Lehmann et al [32].

The seeds of Amaranthus cruentus in their lipid fraction contain a similar amount of $\alpha$-tocopherol as the oil obtained from rape seeds [33], which are commonly used in the diet of Polish people. The amounts of $\alpha$-tocopherol in the seeds of Polish varieties of Amaranthus cruentus that were obtained in this experiment are lower, and the amounts of $\beta$-tocopherol are higher than these obtained by Lehmann at al [32]. However, the results are close to the values obtained in the studies of Polish varieties of amaranthus in the environment of south-eastern Poland [27]. Moreover, it should be noted that the amounts of $\gamma$ - and $\delta$-tocopherol in the seeds of Aztek variety, that were obtained in this study, are higher than these obtained for this variety of amaranthus by Lehmann et al [32] and comparable with Rawa variety.

Mean total amount of isomer of tocopherols in the seeds of amaranthus, Aztek variety, was by $38.8 \%$ higher than in the seeds of Rawa variety. Total content of tocopherol in the seeds of Rawa variety was 55.2 and $76.6 \mathrm{mg} \cdot \mathrm{kg}^{-1} \mathrm{~d} . \mathrm{m}$. for Aztek variety (Table 2). The mean content of tocopherols $(\alpha-, \beta-, \gamma$ - and $\delta$-tocopherol) in the seeds of Amaranthus cruentus is $4.94 \mathrm{mg} \cdot 100 \mathrm{~g}^{-1} \mathrm{~d}$.m. seeds, but this value may vary within the range from 2.80 to $7.80 \mathrm{mg} \cdot 100 \mathrm{~g}^{-1} \mathrm{~d} . \mathrm{m}$. [31]. The values of mean total content of tocopherols in the seeds of the investigated varieties of amaranthus, that were obtained in this experiment, are within the given range. However, it should be emphasized that the use of the third and the fourth 
dosages of fertilizers on amaranthus, Aztek variety, enhanced an increase in the total amount of tocopherols. Their amount was higher than that given by Gunstone et al [31].

\section{Conclusions}

1. The amount of fat in the seeds of amaranthus largely depended on the variety of the plant and the variant of fertilization with macroelements. Particularly large amounts of fat in the seeds were obtained at the highest level of fertilization with NPK. A higher content of fat in seeds was observed in Aztek variety than in Rawa variety.

2. The varieties of amaranthus significantly varied in the content of $\alpha$ - and $\beta$-tocopherol, and their total amount. Higher content of $\alpha$-tocopherols and their total amount was found in the seeds of Aztek variety, than in Rawa variety. The seeds of Rawa variety had significantly more $\beta$-tocopherol than in Aztek variety.

3. Fertilization with increasing dosages of NPK had a significant, positive effect only on the amount of $\alpha$ - tocopherol and its total amount.

\section{References}

[1] Rutkowska J. Amaranthus - roślina przyjazna człowiekowi. Przegl. Piekar. i Cukier. 2006;1:6-10 (in Polish).

[2] Skwaryło-Bednarz B, Nalborczyk E. Uprawa i wykorzystanie amaranthusa. Wieś Jutra. 2006;4(93):52-55 (in Polish).

[3] Bobrzecka D, Wojciechowska B, Procyk Z, Wojtas A. Zawartość oraz jakość tłuszczu z nasion szarłatu (Amaranthus cruentus L.) w zależności od nawożenia miedzią. Rośliny Oleiste. 2000;XXI(10):301-308 (in Polish).

[4] Grajeta H. Wartość odżywcza i wykorzystanie szarłatu (rodzaj Amaranthus). Bromat Chem Toksykol. 1997;30:17-23 (in Polish).

[5] Skwaryło-Bednarz B, Brodowska MS. Amaranth (Amaranthus cruentus L.) as a plant with pro-health properties. In: Pierwiastki, środowisko i życie człowieka. Pasternak K, editor; Lublin: Wyd. Polskie Towarzystwo Magnezologiczne; 2009:280-287.

[6] Prokopowicz D. Właściwości zdrowotne szarłatu (Amaranthus cruentus L.). Medycyna Wet. 2001;57(8):559-562 (in Polish).

[7] Skwaryło-Bednarz B, Krzepiłko A. The effect of various NPK fertilizer doses on total antioxidant capacity of soil and amaranth leaves (Amaranthus cruentus L.). Int Agrophys. 2009;23(1):61-66.

[8] Januszewska-Jóźwiak K, Synowiecki J. Charakterystyka i przydatność składników szarłatu w biotechnologii żywności. Biotechnologia. 2008;3(82):89-102 (in Polish).

[9] Bartnik M, Filipek A. Badanie nad wybranymi wskaźnikami wartości odżywczej nasion i liści amarantusa. Żyw Człow Metabol.1999;26: 229-241 (in Polish).

[10] Szot B. Właściwości agrofizyczne amaranthusa. Acta Agrophys. 1999;18:7-73 (in Polish).

[11] Songin H. Szarłat. [In:] Szczegółowa uprawa roślin. Part I. Jasińska Z, Kotecki A, editors; Wrocław: Wyd. AR; 1999:235-262 (in Polish).

[12] Dodok L, Modhir AA, Halásová G, Poláček I, Hozová B. Importance and utilization of amaranth in food industry Part I. Characteristic of grain and average chemical constitution of whole amaranth flour. Molec Nutri \& Food Res. 1994;38(4):378-381. DOI: 10.1002/food.19940380405.

[13] Jahaniaval F, Kakuda Y, Marcone MF. Fatty acid and triacylglycerol composition of seed oils of five Amaranthus accessions and their comparison to other oils. J Amer Oil Chemists Soc. 2000;77:847-852. DOI: $10.1007 / \mathrm{s} 11746-000-0135-0$.

[14] Nalborczyk E, Wróblewska E, Marcinkowska E, Roszewski R. Amaranthus - perspektywy uprawy i wykorzystania. Warszawa: Wyd. SGGW; 1994 (in Polish).

[15] Sabeena-Farvin KH, Anandan R, Hari Senthil Kumar S, Shiny KS, Mathew S, Sankar TV, Viswanathan Nair PG. Cardioprotective effect of squalene on lipid profile in isoprenaline-induced myocardial infarction in rats. J Med Food. 2006;9:531-536. DOI: 10.1089/jmf.2006.9.531.

[16] Paśko P, Bednarczyk M. Szarłat (Amaranthus spp.) - możliwości wykorzystania w medycynie. Bromat Chem Toksykol. 2007;XL(2):217-222 (in Polish). 
[17] Lehmann JW. Case history of a grain amaranth as an alternative crop. Cereal Foods World. 1996;41:399-411.

[18] Berganza BE, Moran AW, Rodriguez GM, Coto NM, Santamaria M, Bressani R. Effect of variety and location the total fat, fatty acids and squelene content of amaranth. Plant Foods Human Nutr. 2003;58:1-6. DOI: 10.1023/B:QUAL.0000041143.24454.0a.

[19] Słowiński M, Gątarz J. Effect of amaranth flour on quality characteristic of finely comminuted sausages. Rocz Inst Przem Mięsn i Tłuszcz. 2007;XLV(2):79-86.

[20] Bruni R, Medici A, Guerrini A, Scalia S, Poli F, Muzzoli M, Sacchetti G. Wild Amaranthus caudatus seed oil, a nutraceutical resource from Ecuadorian flora. J Agric Food Chem. 2001;49:5455-5460. DOI: $10.1021 / \mathrm{jf} 010385 \mathrm{k}$.

[21] Szymańska R, Nowicka B, Kruk J. Witamina E - metabolizm i funkcje. Kosmos. 2009;58(1-2):199-210 (in Polish).

[22] Li Y, Wang Z, Sun X, Tang K. Current opinions on the functions of tocopherol based on the genetic manipulation of tocopherol biosynthesis in plant. J Int Plant Biol. 2008;50:1057-1069. DOI: $10.1111 /$ j.1744-7909.2008.00689.x.

[23] Wijtmans M, Pratt DA, Valgimigli L, Dilabio GA. 6-amino-3-pyridinols: towards diffusion-controlled chain-breaking antioxidants. Angew Chem Int Ed Engl. 2003;42:4370-4373. DOI: 10.1002/anie.200351881.

[24] Nogala-Kałucka M, Lampart-Szczapa E, Krzyżostaniak I, Siger A. Natywne antyoksydacyjne biokomponenty preparatów łubinowych. Żywn Nauka, Techn, Jakość. 2009;4(65):70-78 (in Polish).

[25] Tömösközia S, Baracskaia I, Schönlechnerb R, Berghoferb E, Lásztitya R. Comparative study of composition and technological quality of amaranth. Gross chemical composition, amino acid and mineral content. Acta Aliment. 2009;38(3):341-347. DOI: 10.1556/AAlim.38.2009.3.8.

[26] Bressani R. Composition and nutritional properties of amaranth. In: Amaranth - Biology, Chemistry and Technology. Paredes-Lopez O, editor; London: CRC Press; 1994:185-206.

[27] Skwaryło-Bednarz B. Zawartość tłuszczu oraz tokoferoli w nasionach krajowych odmian szarłatu (Amaranthus cruentus L.) w warunkach zróżnicowanego nawożenia makroelementami. Acta Agrophys. 2010;15(2):407-415 (in Polish).

[28] Ratusz K, Wirkowska M. Charakterystyka nasion i lipidów amarantusa. Oilseed Crops. 2006;XXVII(2):243-250 (in Polish).

[29] Gajewska R, Lebiedzińska A, Malinowska E, Szefer P. Ocena jakości zdrowotnej szarłatu (amarantusa). Roczn PZH. 2002;53(2):141-147 (in Polish).

[30] Bressani R, Gonzales JM, Elias LG, Melgar M. Effect of fertilizer application on the yield, protein and fat content, and protein quality of raw and cooked grain of three amaranth species. Plant Foods for Human Nutr. 1987;37:59-67. DOI: 10.1007/BF01092301.

[31] Gunstone FD, Harwood JL, Dijkstra AJ. The Lipid Handbook. CRC Press, Taylor \& Francis Group; 2007.

[32] Lehmann JW, Putnam DH, Qureshi AA. Vitamin E isomers in grain amaranth (Amaranthus spp.). Lipids. 1994;29(3):177-181. DOI: 10.1007/BF02536726.

[33] Leon-Camacho M, Garcia-Gonzalez DL, Aparicio R. A detailed and comprehensive study of amaranth (Amaranthus cruentus L.) oil fatty profile. Eur Food Res Technol. 2001;213:349-355. DOI: $10.1007 / \mathrm{s} 002170100340$.

\title{
OCENA ZAWARTOŚCI TEUSZCZU I TOKOFEROLI W NASIONACH SZARŁATU W ZALEŻNOŚCI OD ZRÓŻNICOWANEGO NAWOŻENIA MAKROELEMENTAMI
}

\author{
Wydział Nauk Rolniczych w Zamościu, Uniwersytet Przyrodniczy w Lublinie
}

\begin{abstract}
Abstrakt: Podstawę pracy stanowi doświadczenie polowe przeprowadzono w latach 2007-2008 na polu rolnika indywidualnego w miejscowości Bodaczów k. Zamościa. Celem doświadczenia było określenie wpływu różnych dawek NPK na zawartość tłuszczu oraz homologów tokoferolu w nasionach dwóch odmian amaranthusa: Rawa i Aztek. Eksperyment założono na glebie brunatnej wytworzonej z lessu, o dużej zasobności w P, K i Mg oraz lekko kwaśnym odczynie (pH w $\left.1 \mathrm{~mol} \mathrm{KCl} \cdot \mathrm{dm}^{-3}-5,8\right)$. Doświadczenie założono metodą split-plot $\mathrm{w}$ trzech powtórzeniach. W doświadczeniu przyjęto następujące czynniki: dwie odmiany szarłatu (Rawa i Aztek) oraz 4 warianty nawożenia makroelementami NPK $\left(\mathrm{kg}^{-h^{-1}}\right)\left(\mathbf{1}\right.$ - obiekt bez nawożenia, 2 - $70 \mathrm{~N}, 50 \mathrm{P}_{2} \mathrm{O}_{5}, 50 \mathrm{~K}_{2} \mathrm{O} ; \mathbf{3}$ - $90 \mathrm{~N}, 60 \mathrm{P}_{2} \mathrm{O}_{5}$,
\end{abstract}


$60 \mathrm{~K}_{2} \mathrm{O} ; 4-130 \mathrm{~N}, 70 \mathrm{P}_{2} \mathrm{O}_{5}, 70 \mathrm{~K}_{2} \mathrm{O}$ ). W nasionach oznaczono zawartość tłuszczu metodą Soxhleta oraz $\alpha-, \beta-, \gamma$ - i $\delta$-tokoferol metoda wysokosprawnej chromatografii cieczowej (HPLC). Z przeprowadzonych badań wynika, iż ilość zgromadzonego tłuszczu w nasionach amaranthusa była statystycznie istotnie uzależniona od odmiany oraz wariantu nawożenia makroelementami. Szczególnie dużą zawartość tłuszczu w nasionach uzyskano przy czwartym najwyższym poziomie nawożenia NPK. Większą zawartością tłuszczu w nasionach cechowała się odmiana Aztek niż Rawa. Odmiany amaranthusa statystycznie istotnie różniły się między sobą zawartością: $\alpha$-, $\beta$-tokoferolu i całkowitą ich ilością. Większą zawartością $\alpha$-tokoferoli oraz całkowitą jego ilością cechowały się nasiona odmiany Aztek niż Rawa. Nasiona odmiany Rawa miały statystycznie istotnie więcej $\beta$-tokoferolu niż odmiany Aztek. Nawożenie wzrastającymi dawkami NPK miało statystycznie istotny, dodatni wpływ tylko na ilość $\alpha$-tokoferolu.

Słowa kluczowe: amaranthus, zawartość tłuszczu, tokoferole 